\title{
Molecular Mechanisms of Cardiovascular Aging
}

\author{
Anna Meiliana $^{1,2, *}$, Andi Wijaya ${ }^{1,2}$ \\ ${ }^{1}$ Postgraduate Program in Clinical Biochemistry, Hasanuddin University, Jl. Perintis Kemerdekaan Km.10, Makassar, Indonesia \\ ${ }^{2}$ Prodia Clinical Laboratory, Jl. Cisangkuy No.2, Bandung, Indonesia \\ *Corresponding author. E-mail: anna.meiliana@prodia.co.id
}

\section{Abstract}

$\mathrm{B}$ ACKGROUND: The average lifespan of humans is increasing, and with it the percentage of people entering the 65 and older age group is growing rapidly and will continue to do so in the next 20 years. Within this age group, cardiovascular disease will remain the leading cause of death, and the cost associated with treatment will continue to increase. Aging is an inevitable part of life and unfortunately poses the largest risk factor for cardiovascular disease.

CONTENT: We provide an overview of some of the molecular mechanisms involved in regulating lifespan and health, including mitochondria, telomeres, stem cells, sirtuins, Adenosine Monophosphate-activated Protein Kinase, Mammalian Target of Rapamycin and Insulin-like Growth Factor 1. We also provide future perspectives of lifespan and health, which are intimately linked fields.

SUMMARY: Aging remains the biggest non-modifiable risk factor for cardiovascular disease. The biological, structural and mechanical changes in senescent cardiovascular system are thought to contribute in increasing incidence of cardiovascular disease in aging. Understanding the mechanisms contributing to such changes is therefore crucial for both prevention and development of treatment for cardiovascular diseases.

KEYWORDS: cardiovascular aging, mitochondria, telomeres, Sirtuin, stem cells

Indones Biomed J. 2013; 5(3): 139-50

\section{Abstrak}

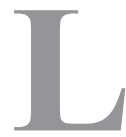

ATAR BELAKANG: Rata-rata usia harapan hidup manusia terus meningkat, hingga 20 tahun ke depan jumlah persentase manusia yang berusia lebih dari 65 tahun akan terus bertambah. Pada kelompok usia ini, penyakit kardiovaskular merupakan penyebab kematian yang utama, dan biaya pengobatannya juga akan terus meningkat. Penuaan merupakan bagian yang tidak dapat dihindari dalam hidup dan sayangnya merupakan faktor risiko terbesar untuk penyakit kardiovaskular.

ISI: Kami akan membahas beberapa mekanisme molekular yang terlibat dalam pengaturan proses penuaan dan kesehatan, meliputi mitokondria, telomer, sel punca, sirtuin, Adenosine Monophosphate-activated Protein Kinase, Mammalian Target of Rapamycin, dan Insulin-like Growth Factor 1. Kami juga membahas pandangan ke depan mengenai proses penuaan dan kesehatan yang keduanya saling terkait.

RINGKASAN: Proses penuaan merupakan faktor risiko utama yang tidak dapat dimodifikasi untuk penyakit kardiovaskular. Perubahan biologis, struktural, dan mekanis pada proses penuaan sistem kardiovaskular memiliki peran pada peningkatan kejadian penyakit kardiovaskular pada usia lanjut. Memahami mekanisme molekular yang berperan pada perubahan tersebut sangatlah penting, baik untuk pencegahan maupun pengembangan terapi penyakit kardiovaskular.

KATA KUNCI: penuaan kardiovaskular, mitokondria, telomer, Sirtuin, sel punca 


\section{Introduction}

Aging is inevitable. Yet for centuries people have tried to slow or stop it, from bathing in the blood of virgin girls to concocting an elixir of life. These days, anti-aging research is on a more scientific footing. And while we are no closer to finding the fountain of youth, humans for a variety of reasons are living longer than ever before.(1)

The World Health Organization estimated that there were 650 million senior citizens in 2007 and the figure is predicted to triple in the next 50 years with about $80 \%$ of the elderly population living in developing countries. (2) Both aging and disease result in the same outcome: the impairment of normal biological function. It would not, therefore, be a surprise if tissue dysfunction resulting from an aging mechanism eventually manifested itself as a disease. Therefore, understanding mechanisms of aging would help understand the processes which govern the development and progression of some diseases. This in turn would lead to the development of new therapeutic methods for disease treatment and, more importantly, prevention.

Cellular senescence is the irreversible growth arrest of individual mitotic cells, which as a consequence display a radically altered phenotype that is thought to impair tissue function and predispose tissues to disease development and/or progression as they gradually accumulate. When discussing the impact of senescent cells may have on aging and age-related disease, it is important to take into consideration factors which may result in the removal and replacement of senescent cells. These include apoptosis and the availability of stem cell reserves.(3)

It is not clear to what extent both stem cells and somatic cells play in tissue regeneration, but the functional ability of stem cells appears to become impaired with age.(4) Stem cells express telomerase and are unlikely to become senescent in response to telomere shortening. Some of the changes observed during cellular senescence are likely to be cell-type specific. For example, in senescent vascular endothelial cells, endothelial Nitric Oxide Synthase (eNOS) activity has been found to be decreased.(5,6) Since Nitric Oxide (NO) is important in regulating vascular function, a decline in its production may have detrimental consequences. A reduction in NO production by eNOS, for example, has been suggested to be a significant risk factor for cardiovascular disease (CVD).(7) Aging of the vasculature results in increased arterial thickening and stiffness as well as dysfunctional endothelium. Clinically, these changes result in increased systolic pressure and present major risk factors for development of atherosclerosis, hypertension and stroke, and arterial fibrillation.(8)

Aging, although an unavoidable cardiovascular risk factor, may overcome all other risk factors collectively. Therefore, understanding fundamental mechanisms that dictate the pace of aging could lead to significant advancements into both preventative and therapeutic treatments of CVD.(9)

\section{Aging and CVD}

The most important determinant of cardiovascular health is a person's age. By 2030, approximately $20 \%$ of the population will be aged 65 or older. In this age group, CVD will result in $40 \%$ of all deaths and rank as the leading cause. Furthermore, the cost to treat CVD will triple in that time. $(10,11)$ Hence, it remains vital that we understand why age is such a critical component of CVD etiology. However, until recently, the fields of CVD and molecular biology of aging have remained largely separate. Aging is associated with a progressive decline in numerous physiological processes, leading to an increased risk of health complications and disease. By delivering oxygenated blood to all tissues in the body, the health of the cardiovascular system is vital for health of every tissue and longevity of the organism as a whole. Aging has a remarkable effect on the heart and arterial system, leading to an increase in CVD including atherosclerosis, hypertension, myocardial infarction, and stroke.(12)

A common feature of aging tissues is low-level chronic inflammation, termed sterile inflammation (indicating an absence of detectable pathogens) or inflammaging.(13-16) Chronic inflammation can drive pathology by at least two mechanisms. First, infiltrating immune cells can degrade tissues because they release reactive or toxic moieties. Second, inflammatory cytokines can provoke phenotypic changes that are independent of the immune system in nearby cells. For example, Interleukin-6 (IL-6) and IL-8 can stimulate angiogenesis, disrupt cell-cell communication, impede macrophage function, induce innate immune responses, and promote epithelial and endothelial cell migration and invasion.(17-23) This chronic inflammation may derive partly from an age-related metabolic dysfunction.

Fat tissue, frequently the largest organ in humans, is at the nexus of mechanisms involved in longevity and agerelated metabolic dysfunction. Fat distribution and function change dramatically throughout life.(24) Cellular stress and preadipocyte overutilization with aging induce cellular senescence, leading to impaired adipogenesis, failure to sequester lipotoxic fatty acids, inflammatory cytokine and chemokine generation, and innate and adaptive immune response activation. These pro-inflammatory processes may 
amplify each other and have systemic consequences.(24)

Chronic inflammation may also derive in part from senescent cells: senescent cells secrete pro-inflammatory cytokines, chemokines, and proteases, termed the Senescence-associated Secretory Phenotype (SASP). $(25,26)$ SASP is primarily a DNA Damage Response (DDR).(27) The SASP, through the inflammatory, growthpromoting, and remodeling factors that it produces, can potentially explain how senescent cells alter tissue microenvironments, attract immune cells, and, ironically, induce malignant phenotypes in nearby cells. Proteins that are associated with the SASP, such as Tumor Necrosis Factor alpha (TNF- $\alpha$ ), IL-6, Matrix Metalloproteinases (MMPs), Monocyte Chemoattractant Protein-1 (MCP-1), and Insulinlike Growth Factor Binding Proteins (IGFBPs), increase in multiple tissues with chronological aging(28), and occur in conjunction with sterile inflammation. This finding suggests that SASP is the main driver of age-related inflammation, at least in fat tissue under certain conditions. Thus, selective elimination of senescent cells or their effects might be a means to reduce age-related sterile chronic inflammation, enhance health span, and interrupt the link between aging and chronic disease.(29) Measuring cardiac-specific senescence, DNA damage, as well as levels of apoptosis and necrosis, coupled with fibrosis measurements in animal models of aging, will lead to a better understanding of the link between aging and CVD.(9)

\section{Mitochondria and Cardiovascular Aging}

The prevalence of CVD increases dramatically with advancing age. More than $80 \%$ of cases of coronary artery disease and $\sim 75 \%$ of cases of congestive heart failure are observed in geriatric patients.(30)

Mitochondria plays important roles in a myriad of cellular processes including Adenosine Triphosphate (ATP) production via oxidative phosphorylation, biosynthetic pathways, cellular redox homeostasis, ion homeostasis, oxygen sensing, signaling, and regulation of programmed cell death. Mitochondrial dysfunction is central to theories of aging, because age-related changes of mitochondria are likely to impair a host of cellular physiological functions in parallel and contribute to the development of all common age-related diseases.(31) The evidence supporting the role of mitochondrial oxidative stress, mitochondrial damage and biogenesis as well as the crosstalk between mitochondria and cellular signaling in cardiac and vascular aging.

Aging is known to be associated with mutations in genes of mitochondrial genome, which encodes key proteins of respiratory complex, including components of electron transport chain and ATP synthase complexes.(32)
Considerable evidence has been published that with advanced age mitochondrial production of Reactive Oxygen Species (ROS) significantly increases both in the heart(33) and the vasculature(34). Age-dependent mitochondrial dysfunction is closely correlated with abnormal mitochondrial ROS production and detoxification.(35-37) Mitochondriaderived ROS are likely to contribute to the development of chronic low-grade vascular inflammation in aging(34) by activating redox signaling pathways. Furthermore, recent studies suggest that mitochondria-derived ROS contribute to accelerated development of the senescent phenotype in endothelial cells (i.e., by activating Akt.(28) Endothelial cell senescence may impair regenerative and angiogenic capacity of endothelium, its reactivity and promote progression of atherosclerosis by altering secretion of cytokines, growth factors, and proteases in vascular wall. Another potentially important link between mitochondrial oxidative stress and vascular aging is induction of apoptosis. $(38,39)$ Oxidative stress in aging is associated with an increased rate of endothelial apoptosis $(40,41)$, which may contribute to microvascular rarefaction impairing the blood supply of heart(42) and brain(43).

The molecular mechanisms underlying agerelated increases in mitochondrial oxidative stress in the cardiovascular system are multifaceted and likely involve cell-autonomous effects, including a significant decline in reduced glutathione content (44), dysregulation of antioxidant defense mechanisms (e.g., peroxynitritemediated nitration and inhibition of Manganese Superoxide Dismutase (MnSOD))(39), and a dysfunctional electron transport chain $(45,46)$. Recent studies suggest that age-related changes in endocrine/paracrine regulatory mechanisms-including activation of the renin-angiotensinaldosterone system, adrenergic signaling, and an agerelated dysfunction of growth hormone/Insulin-like Growth Factor-1 (IGF-1) signaling also have an important role in promoting mitochondrial oxidative stress in the aged cardiovascular system.(31)

In heart and the vasculature of young animals in response to increased production of mitochondria-derived ROS, an adaptive Nuclear Factor (NF)-E2-related factor 2 (Nrf2)-driven antioxidant defense mechanism manifests, which upregulates Antioxidant Response Element (ARE)driven expression of detoxifying and antioxidant enzymes and the cystine/glutamate transporter involved in glutathione biosynthesis. $(47,48)$ Recent findings demonstrate that in aging vessels increased production of ROS by mitochondria and other sources fails to activate Nrf2 resulting in increased cellular sensitivity to the deleterious effects of oxidative stressors.(47-49) 
Mitochondria are highly dynamic organelles, and dysregulation of mitochondrial turnover is likely one of the intrinsic causes of mitochondrial dysfunction, which contributes to dysregulation of cell metabolism, oxidative stress, and altered signal transduction during the aging process.(50) The removal of dysfunctional mitochondria through autophagy is crucial for the maintenance of cell viability.(51) The efficiency of this process declines with advancing age, which may be critically involved in heart senescence and in age-related CVD. $(52,53)$ Regardless of the mechanism(s) primarily responsible for mitochondrial decay during aging, mitochondrial quality control is essential for the preservation of cardiomyocyte homeostasis. This task is accomplished through the complex coordination of several processes.(54)

Mitophagy is a highly selective process that can promote the elimination of dysfunctional or unnecessary mitochondria. The loss of mitochondrial membrane potential $(\Delta \psi \mathrm{m})$ represents a major trigger of mitophagy. (55) Although the molecular regulation of mitophagy has not yet been completely elucidated, the Mammalian Target of Rapamycin (mTOR)/Adenosine Monophosphate (AMP)-activated Protein Kinase (AMPK) pathway is proposed to be a major checkpoint.(56) AMPK, in addition to stimulating mitochondrial removal through autophagy, enhances activity of Sirtuin-1 (SIRT1) and its downstream target Peroxisome Proliferator-activated Receptor gamma Coactivator-1 alpha (PGC-1 $\alpha$ ), resulting in stimulation of mitochondrial biogenesis.(57) Hence, through the activity of AMPK, mitophagy and mitochondrial biogenesis are coordinately regulated, maintaining a healthy and functional pool of mitochondria in the cell.(58)
Aging is associated with impaired mitochondrial biogenesis and reduced mitochondrial mass in the vascular endothelial and smooth muscle cells. $(46,59,60)$ Available evidence suggests that in the aged vasculature, because of an increased production of ROS and downregulation and uncoupling of eNOS, the bioavailability of NO is significantly decreased(61), which results in a downregulation of PGC- $1 \alpha$ and consequential dysregulation of constituents of the electron transport chain and other mitochondrial proteins(46). It is likely that decreased NO bioavailability is causally linked to dysfunction of mitochondrial biogenesis in other organs as well during aging. $(60,62)$ Aging-associated phenotypes have been linked not only to mitochondrial dysfunction but also to aberrant mitochondrial biogenesis caused by impaired retrograde signaling regulated by nuclear genes and factors dependent on mitochondrial metabolism (e.g., ATP, $\mathrm{Ca}^{2+}$, ROS, NO, Nicotinamide Adenine Dinucleotide (NAD) $\left.{ }^{+} / \mathrm{NADH}\right) .(63)$ Pathways that improve mitochondrial function, attenuate mitochondrial oxidative stress, and regulate mitochondrial biogenesis have recently emerged as potential therapeutic targets for prevention of the development of age-related CVD.

The important role of mitochondrial oxidative stress and mitochondrial dysfunction in age-related cardiovascular pathologies is evident, and we are at the beginning of an exciting phase of research on understanding the genetic and epigenetic mechanisms underlying the mitochondrial alterations that occur with age.(31)

\section{Telomeres and Cardiovascular Aging}

Hypothesized molecular mechanisms for aging in modern biology have abounded. These have included stem cell

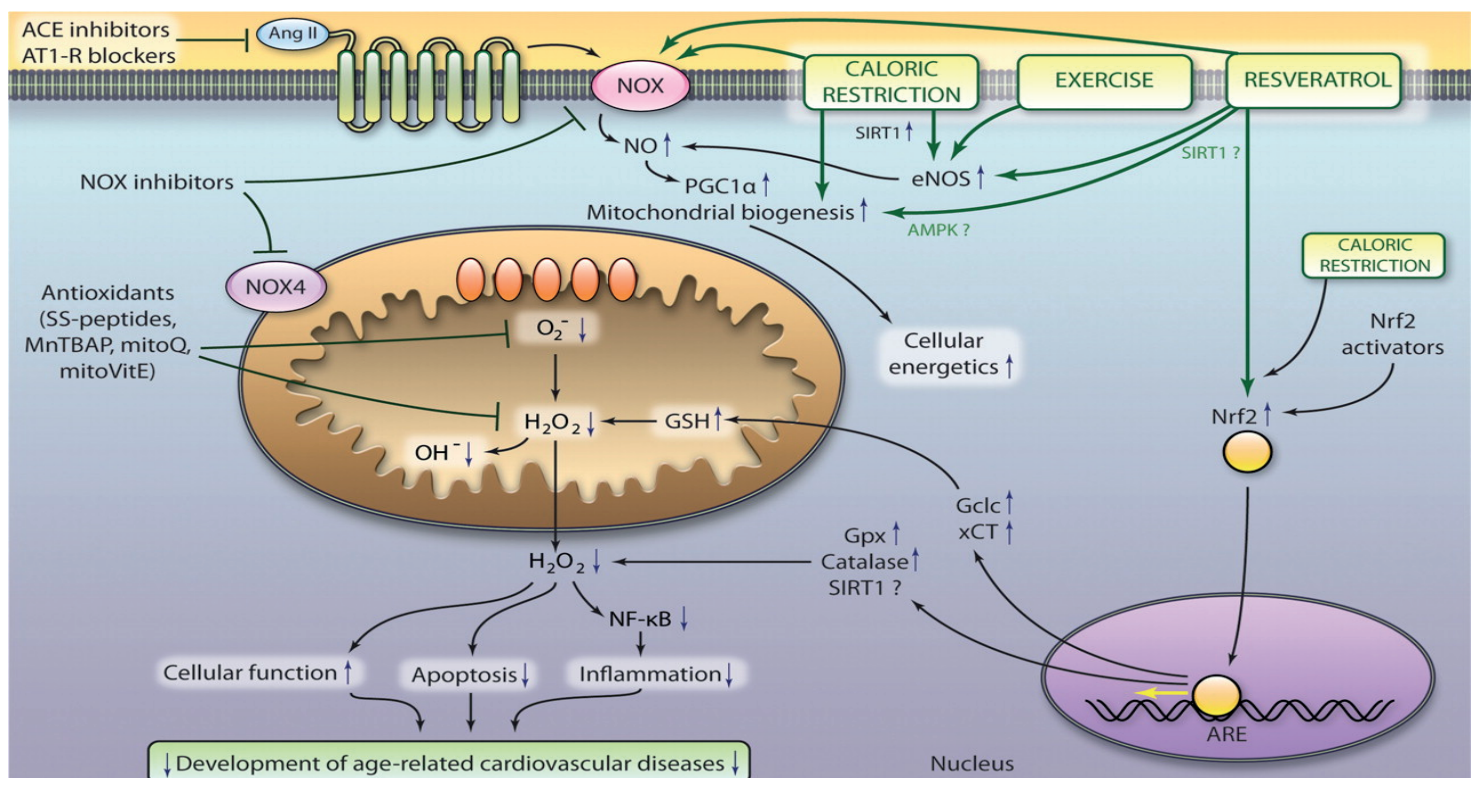

Figure 1. Summary of mitochondrial-targeted interventions and their therapeutic potential in aging.(31) (Adapted with permission from American Heart Association). 
failure, mitochondrial dysfunction, genotoxic stress, and epigenetic changes. Recent cumulative evidence points to telomere shortening as sufficient to provoke all these mechanisms. The manifestations of telomere-mediated disease, especially in adults, can be subtle and are often indistinguishable from the slow, gradual functional decline that is a hallmark of aging. The compelling clinical evidence therefore points to telomere shortening itself as being sufficient, or perhaps more broadly representing forms of genotoxic stress that contribute to age-related changes.(64)

Telomeres define the ends of linear chromosomes. They are made up of repetitive DNA sequences that are bound by specialized proteins. The human telomeric DNA sequence is a tandem repeat of TTAGGG that extends several kilobases.(65-67) The telomere-binding complex of proteins, known as shelterin, together with telomere DNA, functions as a dynamic unit that protects chromosome ends from being recognized as broken DNA, thus preventing their degradation and participation in fusion events.(68) Telomeres are therefore essential for the maintenance of genomic integrity. Telomerase is the specialized polymerase that synthesizes new telomere repeats. $(69,70)$ It offsets the shortening that normally occurs with cell division since the replication machinery does not copy fully to the ends. Telomerase has two essential core components, Telomerase Reverse Transcriptase (TERT) and Telomerase RNA (TR), the latter of which provides the template for telomere repeat addition.(71-73) Telomeres have long been linked to processes of cellular aging. Telomere length shortens with age and predicts the onset of replicative senescence. When telomeres become critically short, they become dysfunctional and activate a DNA damage response that resembles double-strand breaks.(74) The resulting signaling cascade provokes apoptosis and/or a permanent cell cycle arrest that, until recently, has been considered the primary functional consequence of senescence.(64)

Cumulative studies in humans with telomere maintenance disorders and telomerase knock-out mice have demonstrated that short telomeres precipitate functional decline in different tissues, including the cardiovascular system.(75) Mechanistically, telomere dysfunction-driven tissue compromise is thought to be secondary to the activation of DNA damage signaling pathways that converge on $\mathrm{p} 53$, a central executor of the DNA damage response pathway.(76) p53 activation induces senescent and apoptosis pathways, particularly in stem cell and progenitor compartments of highly regenerative organs. The elimination of stem and progenitor cells is thought to be the driving force in the development of tissue defects.(77)

Telomere dysfunction-activated p53 directly leads to mitochondrial and metabolic compromise through the repression of the master regulators of mitochondrial biogenesis and function, PGC-1 $\alpha$ and PGC-1 $1 \beta .(78)$ Given that an accelerated rate of telomere shortening may be expected from the increased cellular turnover associated to inflammation occurring in atherosclerosis, and from the action of several cardiovascular risk factors (e.g., oxidative stress, hypertension, diabetes, smoking, psychological stress), telomere exhaustion may be a surrogate marker of CVD.(79)

\section{Sirtuin, Class O of Forkhead Box Transcription Factors (FOXO) and Cardiovascular Aging}

Age is one of the major risk factors associated with CVD. Part of this complex phenomenon is the deterioration of tissues that constitute heart and its associated vasculature. Aging results in a progressive functional and structural decline in multiple organs, and in particular, has profound effects on heart and arterial system. Age-related cardiac and vascular changes include impaired endothelial function and intimal proliferation(80), increased arterial stiffness(8,81-85), left ventricular (LV) diastolic dysfunction(12,86,87), LV pathological hypertrophy(88), diminished LV systolic reverse capacity $(12,87)$, decreased heart rate variability(89-91), and a reduction in maximal heart rate(92). Furthermore, as a consequence of aging, the interaction between the heart and arterial system is altered to preserve ventricle-arterial homeostasis.

Sirtuins post-translationally modulate the function of many cellular proteins that undergo reversible acetylationdeacetylation cycles, affecting physiological responses that have implications for treating diseases of aging.(93) Sirtuin proteins bolster stress resistance of mammalian cells by virtue of their abilities to remodel metabolism, alter inflammatory responses, and enhance the ability to cope with oxidative species. Because many of these same pathways are pathologically altered in the aged, activation of sirtuins represents a feasible means for attenuating agerelated CVD.(94)

In mammals there are seven members of the sirtuin family, SIRT1-7, of which SIRT1 has become the most well-studied protein. The expression level of SIRT1 increases upon calories restriction (CR) in several rodent and human tissues, such as white adipose, liver, skeletal muscle, brain and kidney.(95-98) SIRT1 activates PGC$1 \alpha$ by deacetylation of lysine residues $(99,100)$, which results in increased mitochondriogenesis $(99,101)$. A decline in mitochondrial function with age is thought to be a contributing factor to insulin resistance and agerelated cancers. $(102,103)$ Interestingly, CR elicits similar 
improvements in mitochondrial function.(104-107) Therefore, it is possible that a small-molecule activator of SIRT1 may activate some of the same pathways that are modified by $\mathrm{CR}$ and could be a therapy for diseases of aging.

Two different enzymatic activities have been reported for the sirtuins: an Adenosine Diphosphate (ADP)-ribosyl transferase (108,109), and/or a deacetylase activity(110-112). The most important and well-studied protein of this family, SIRT1, is an NAD ${ }^{+}$-dependent deacetylase.(113) The deacetylation reaction removes an acetyl group from the lysine side chains of a protein substrate while cleaving $\mathrm{NAD}^{+}$in the process to generate the deacetylated protein 2'-O-acetyl-ADP-ribose and nicotinamide. Overexpression or activation of SIRT1 has been shown to modulate mitochondrial biogenesis, metabolic rate, insulin sensitivity, glucose and lipid metabolism.(114-119) When there is a limiting supply of fuel substrates to produce the required amount of ATP, concentrations of NAD are elevated. As SIRT1 activity is increased by elevated NAD levels, it may therefore act as a sensor of cellular $\mathrm{NAD}^{+} / \mathrm{NADH}$ levels, contributing to the adaptive changes in the activity of transcription factors, co-activators or co-repressors (for example, nuclear receptor interacting protein 1 (NRIP1), peroxisome proliferate-activated receptor- $\alpha$ (PPAR- $\alpha$ ) and PGC-1 $\alpha$ that have key roles in metabolic adaptations to nutrient availability.

SIRT1 activation can improve cardiac function through effects on multiple pathways including improved vasorelaxation (possibly through K-channel inhibition), anti-inflammatory activity on macrophages and foam-cell formation. This is in addition to increased scavenging of ROS, increased NO synthase activity, reduced platelet aggregation, angiogenesis activity and anti-apoptosis activity.(120-129) As an example, SIRT1 regulates the activity of PGC-1 $\alpha$, a central factor in controlling energy state and contractile function in cardiac muscle.(130)

SIRT1-induced angiogenic activity is probably mediated via FOXO transcription factors that regulate blood vessel endothelial development.(131,132) The interaction between SIRT1 and FOXO proteins also leads to cardioprotection in a p53-dependent manner against a number of different stressors.(133,134) Indeed, SIRT1 expression is elevated during vascular development, whereas loss of its activity leads to limited blood vessel sprouting, defective blood vessel formation and attenuated ischaemia-induced neovascularization.

One of the intermediates in insulin/IGF-1 signaling cascade is activation of serine/threonine kinase Akt/Protein Kinase B (PKB) and Serum/Glucocorticoid-regulated Kinase (SGK).(135) From the standpoint of aging, the most important Akt and SGK substrates appear to be FOXOs. $(136,137)$ Akt and SGK-mediated phosphorylation of FOXOs results in FOXO sequestration in the cytoplasm. Mutations that decrease signaling though the insulin/IGF-1 signalling pathway reduce the phosphorylation of FOXOs, resulting in nuclear translocation.(138,139) In the nucleus, FOXOs modulate the expression of genes that increase lifespan.(140-142) Thus, IGF-1 signaling is likely to promote a chronic aging-promoting effect on cardiomyocytes. These sensitizing effects of growth factor signaling genes in various mammalian cell types may be mediated in part by the inactivation of FOXO forkhead stress resistance transcription factors regulate cellular protection in part by modulating the expression of antioxidant enzymes such as

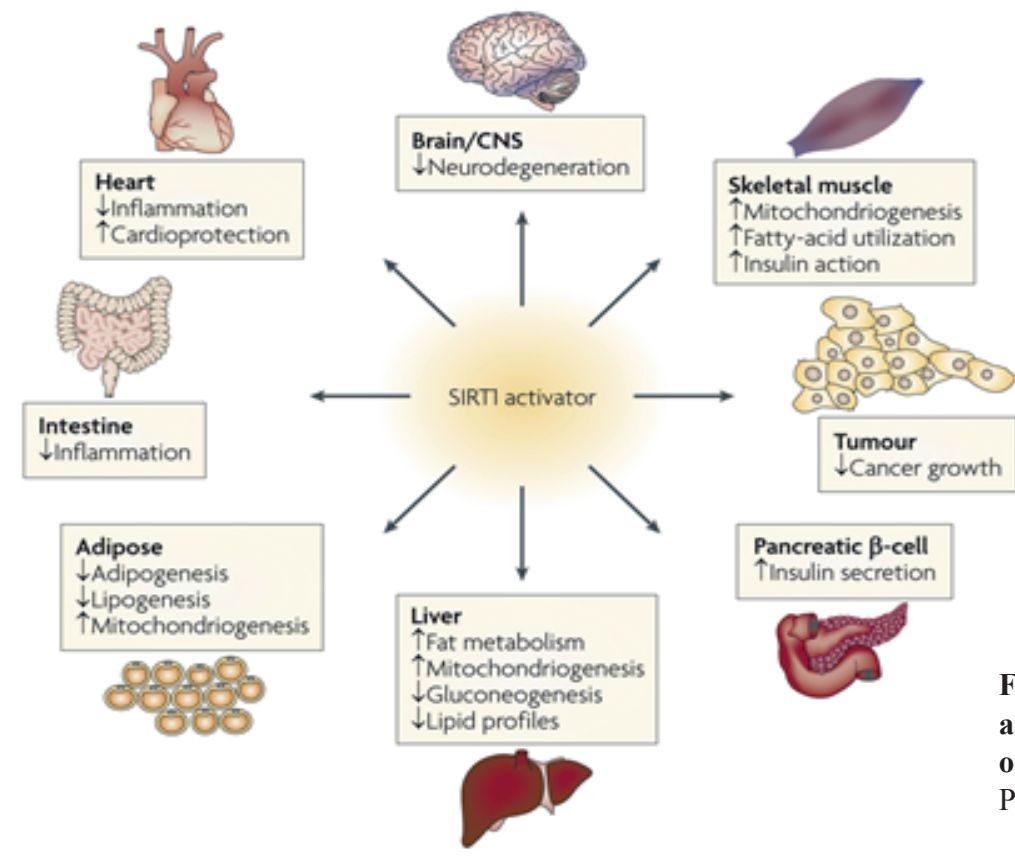

Figure 2. Multiple target organs in which SIRT1 activators can potentially have effects to treat diseases of aging - (93) (Adapted with permission from Nature Publishing Group). 
Superoxide Dismutase-2 (SOD2).(144)

The metabolic effects of FOXO1 vary with the tissue, but they generally antagonize the actions of insulin.(144149) FOXO1 activity itself is negatively regulated by insulin through Akt phosphorylation, which causes it to translocate to the cytoplasm from the nucleus. Whether altered FOXO1 levels or activity can affect lifespan in mammals has not been reported.(150) The integration of individual FOXO and sirtuin family members into various aspects of vessel growth, maintenance, and function provides new perspectives on disease mechanisms of aging, the most important risk factor for medical maladies of the vascular system.(151)

\section{Nutrients and Cardiovascular Aging}

$\mathrm{CR}$, a $20 \%$ to $40 \%$ reduction in calorie intake, which reduces the levels of IGF-1 and other growth factors, has been consistently shown to increase life span and to prevent the development of age-associated cardiovascular functional and structural changes in several model organisms.(152159) In particular, $C R$ has been shown to improve arterial flow-mediated vasodilation $(160,161)$ and to delay the development of atherosclerotic lesions in rodents(154). CR significantly ameliorates LV diastolic function of the aging heart and reduces arterial stiffness. $(153,156,157,160)$ Moreover, long-term $\mathrm{CR}$ has been shown to improve autonomic function and, in particular, to increase the highfrequency component of the heart rate variability spectra, a marker for parasympathetic activity in rats.(158) Finally, long-term $\mathrm{CR}$ has a powerful effect in preventing/delaying the age-related increase in the severity of cardiomyopathy in rodents as well as in monkeys.(159,162,163)

$\mathrm{CR}$, defined as a reduction in food intake without malnutrition, is a robust anti-aging intervention and the most powerful physiological inducer of macroautophagy. (164) The modulation of the autophagic response represents a primary mechanism underlying the lifespanextending properties of CR.(165-167) There are a number of hypotheses regarding the mechanisms by which $\mathrm{CR}$ mediates its beneficial effects on aging in lower organisms that could have relevance to slowing cardiovascular aging in humans. These include a decrease in chronic inflammation, a reduction in the levels of various hormones and growth factors, an increased resistance to oxidative stress, as well as the potentiation of antioxidant defense mechanisms.(168)

The original idea that $\mathrm{CR}$ works passively by suppressing metabolic rate or reducing damage caused by ROS is being replaced by a fundamentally different model in which CR triggers an active defense response that evolved to promote survival during harsh conditions. At the center of this response are so-called "longevity regulatory" pathways, which include IGF-1, mTOR, AMPK and NAD ${ }^{+}$-dependent deacetylases (sirtuins).(9)

Many of the fundamental molecular processes involved in CR-mediated protection of the cardiovascular system are known. CR increases mitochondrial function while reducing oxidative stress in vasculature, in part by inducing expression of the $\mathrm{Nfr} 2$ stress response transcription factor, which induces expression of nicotinamide adenine dinucleotide phosphate-oxidase (NADPH): Quinone Oxidoreductase 1, Heme Oxygenase 1, and Glutathione S Transferase. (169-171) CR also reduces inflammation by suppressing the activity of vascular adhesion molecules, prostanoids, and inflammatory cytokines in both rodents(172) and humans(173). Endothelial function is enhanced and both atherosclerosis and arterial stiffness are reduced by $\mathrm{CR}$ in rodents. $(174,175)$ With regard to cardiac function, CR delays the age-related decline in diastolic filling accompanied by reductions in inflammation, cardiomyopathy, cardiac fibrosis, and myocardial degeneration.(176)

Coenzyme (Co)Q contributes to stabilize plasma membrane, regenerates antioxidants such as ascorbate and $\alpha$-tocopherol, and regulates the extracellularly induced ceramide-dependent apoptosis pathway. $(177,178)$ NAD(P) $\mathrm{H}$-dependent reductases act at the plasma membrane to regenerate $\mathrm{CoQH} 2$, contributing to maintain its antioxidant properties. As a whole, both $\mathrm{CoQ}$ and its reductases constitute a transplasma membrane antioxidant redox system responsible of the above described functions.(179-181) The upregulation of plasma membrane redox system that occurs during $\mathrm{CR}$ decreases the levels of oxidative stress in aged membranes.(182-185) CR modifies composition of fatty acid in plasma membrane, resulting in decreased oxidative damage including lipid peroxidation.(186,187) More importantly, plasma membrane redox activities and also the content of CoQ, which decline with age, are enhanced by $\mathrm{CR}$, providing protection to phospholipids and preventing lipid peroxidation reaction progression.(182-185)

The logical extension of this idea is that it should be possible to mimic the beneficial effects of dieting and exercise by tweaking the right pathways, using small molecules. Studies with "CR mimetics" such as resveratrol and metformin (which activate the SIRT1-AMPK system) or rapamycin (which inhibits mTOR), show that it is possible for a rodent to be obese and sedentary while maintaining the physiology of a lean animal.(114,188-191) Recent work has also identified a secreting hormone termed irisin, which, when increased, induces energy expenditure in the absence of exercise, positively influencing obesity and glucose homeostasis. However, the overall effect of irisin on CVD 
remains largely unexplored.(192)

Resveratrol has been shown to recapitulate the transcriptional profile and some of the physiological changes that develop under CR. Indeed, both CR and resveratrol supplementation inhibit gene expression profiles associated with cardiac aging in mice. In addition, resveratrol improved survival and reduced the prevalence of cardiac pathology in mice fed a high-calorie diet. $(188,193)$

In general, CR may affect vascular health both by improving systemic risk factors for coronary artery disease (e.g., plasma lipid and glucose levels, blood pressure) and by modulating cellular functions and gene expression in endothelial and smooth muscle cells that create a microenvironment in the vascular wall, which does not favor atherogenesis (e.g., attenuation of ROS production, anti-inflammatory effects).(49)

\section{Conclusion}

Aging, although an unavoidable cardiovascular risk factor, may overcome all the other risk factors collectively. Therefore, understanding how aging mechanisms cause alterations to tissues and understanding the consequences of those alterations brings us one step closer to developing new therapeutic ways of treating and, more importantly, preventing the appearance of age-related CVD.

\section{References}

1. Brody H, Grayson M, Scully T, Haines N, Gray A, Dargie R. Aging. Nature. 2012; 492: S1

2. Offord E, Major G, Vidal K, Gentle-Rapinett G, Batge E, Beck T, et al. Nutrition throughout life: innovation for healthy aging. Nestle Research Center [cited on 2014 Jan 3]. Available from: http://www.research.nestle.com/asset-library/documents/ natureoutlookwhitepaperaging_final.pdf

3. Burton DG. Cellular senescence, ageing and disease. Age (Dordr). 2009; 31: 1-9.

4. Sharpless NE, DePinho RA. How stem cells age and why this makes us grow old. Nat Rev Mol Cell Biol. 2007; 8: 703-13.

5. Matsushita H, Chang E, Glassford AJ, Cooke JP, Chiu CP, Tsao PS. eNOS activity is reduced in senescent human endothelial cells: Preservation by hTERT immortalization. Circ Res. 2001; 89:793-8.

6. Minamino T, Miyauchi H, Yoshida T, Ishida Y, Yoshida H, Komuro I. Endothelial cell senescence in human atherosclerosis: role of telomere in endothelial dysfunction. Circulation. 2002; 105:1541-4.

7. Cannon RO 3rd. Role of nitric oxide in cardiovascular disease: focus on the endothelium. Clin Chem. 1998; 44: 1809-19.

8. Lakatta EG, Levy D. Arterial and cardiac aging: major shareholders in cardiovascular disease enterprises, part II: the aging heart in health: links to heart disease. Circulation. 2003; 107: 346-54.

9. North BJ, Sinclair DA. The intersection between aging and cardiovascular disease. Circ Res. 2012; 110: 1097-108.

10. Fleg JL, Aronow WS, Frishman WH. Cardiovascular drug therapy in the elderly: benefits and challenges. Nat Rev Cardiol. 2011; 8: 13-
28.

11. Heidenreich PA, Trogdon JG, Khavjou OA, Butler J, Dracup K, Ezekowitz MD, et al. Forecasting the future of cardiovascular disease in the United States: a policy statement from the American Heart Association. Circulation. 2011; 123: 933-44.

12. Lakatta EG, Levy D. Arterial and cardiac aging: major shareholders in cardiovascular disease enterprises, part II: the aging heart in health: links to heart disease. Circulation. 2003; 107: 356-54.

13. Chung HY, Cesari M, Anton S, Marzetti E, Giovannini S, Seo AY, et $a l$. Molecular inflammation: underpinnings of aging and age-related diseases. Aging Res Rev. 2009; 8: 18-30.

14. Franceschi C, Capri M, Monti D, Giunta S, Olivieri F, Sevini F, et al. Inflammaging and anti-inflammaging: a systemic perspective on aging and longevity emerged from studies in humans. Mech Ageing Dev. 2007; 128: 92-105.

15. Vasto S, Candore G, Balistreri CR, Caruso M, Colonna-Romano G, Grimaldi MP, et al. Inflammatory networks in ageing, age-related diseases and longevity. Mech Ageing Dev. 2007; 128: 83-91.

16. Ferrucci L, Ble A, Bandinelli S, Lauretani F, Suthers K, Guralnik JM. A flame burning within. Aging Clin Exp Res. 2004; 16: 240-3.

17. Ancrile B, Lim KH, Counter CM. Oncogenic Ras-induced secretion of IL6 is required for tumorigenesis. Genes Dev. 2007; 21: 1714-9.

18. Badache A, Hynes NE. Interleukin 6 inhibits proliferation and, in cooperation with an epidermal growth factor receptor autocrine loop, increases migration of T47D breast cancer cells. Cancer Res. 2001; 61: 383-91.

19. Desai TR, Leeper NJ, Hynes KL, Gewertz BL. Interleukin-6 causes endothelial barrier dysfunction via the protein kinase $\mathrm{C}$ pathway. J Surg Res. 2002; 104: 118-23.

20. Naugler WE, Karin M. The wolf in sheep's clothing: the role of interleukin-6 in immunity, inflammation and cancer. Trends Mol Med. 2008; 14: 109-19.

21. Sparmann A, Bar-Sagi D. Ras-induced interleukin-8 expression plays a critical role in tumor growth and angiogenesis. Cancer Cell. 2004; 6: 447-58

22. Tamm I, Kikuchi T, Cardinale I, Krueger JG. Cell-adhesion-disrupting action of interleukin 6 in human ductal breast carcinoma cells. Proc Natl Acad Sci USA. 1994; 91: 3329-33.

23. Nagabhushanam V, Solache A, Ting LM, Escaron CJ, Zhang JY, Ernst JD. Innate inhibition of adaptive immunity: mycobacterium tuberculosis-induced IL-6 inhibits macrophage responses to IFNgamma. J Immunol. 2003; 171: 4750-7.

24. Tchkonia T, Morbeck DE, Von Zglinicki T, Van Deursen J, Lustgarten $\mathrm{J}$, Scrable $\mathrm{H}$, et al. Fat tissue, aging, and cellular senescence. Aging Cell. 2010; 9: 667-84

25. Coppé JP, Patil CK, Rodier F, Krtolica A, Beauséjour CM, Parrinello $\mathrm{S}$, et al. A human-like senescence-associated secretory phenotype is conserved in mouse cells dependent on physiological oxygen. PLoS One. 2010; 5: 9188.

26. Coppé JP, Patil CK, Rodier F, Sun Y, Muñoz DP, Goldstein J, et al. Senescence-associated secretory phenotypes reveal cellnonautonomous functions of oncogenic RAS and the p53 tumor suppressor. PLoS Biol. 2008; 6: 2853-68.

27. Rodier F, Coppé JP, Patil CK, Hoeijmakers WA, Muñoz DP, Raza $\mathrm{SR}$, et al. Persistent DNA damage signaling triggers senescenceassociated inflammatory cytokine secretion. Nat Cell Biol. 2009; 11: 973-9

28. Freund A, Orjalo AV, Desprez PY, Campisi J. Inflammatory networks during cellular senescence: causes and consequences. Trends Mol Med. 2010; 16: 238-46.

29. Tchkonia T, Zhu Y, van Deursen J, Campisi J, Kirkland JL. Cellular senescence and the senescent secretory phenotype: therapeutic opportunities. J Clin Invest 2013; 123: 966-72.

30. Lloyd-Jones D, Adams R, Carnethon M, De Simone G, Ferguson TB, 
Flegal K, et al. Heart disease and stroke statistics-2009 update: a report from the American Heart Association Statistics Committee and Stroke Statistics Subcommittee. Circulation. 2009; 119: 480-6.

31. Dai DF, Rabinovich PS, Ungvari Z. Mitochondria and cardiovascular aging. Circ Res. 2012; 110: 1109-24.

32. Newgard CB, Sharpless NE. Coming of age: molecular drivers of aging and therapeutic opportunities. J Clin Invest. 2013; 123: 946-50.

33. Judge S, Jang YM, Smith A, Hagen T, Leeuwenburgh C. Ageassociated increases in oxidative stress and antioxidant enzyme activities in cardiac interfibrillar mitochondria: implications for the mitochondrial theory of aging. FASEB J. 2005; 19: 419-21.

34. Ungvari ZI, Orosz Z, Labinskyy N, Rivera A, Xiangmin Z, Smith $\mathrm{KE}$, et al. Increased mitochondrial $\mathrm{H} 2 \mathrm{O} 2$ production promotes endothelial NF-kappaB activation in aged rat arteries. Am J Physiol Heart Circ Physiol. 2007; 293: 37-47.

35. Mammucari C, Rizzuto R. Signaling pathways in mitochondrial dysfunction and aging. Mech Ageing Dev. 2010; 131: 536-43.

36. Trifunovic A, Larsson NG. Mitochondrial dysfunction as a cause of ageing. J Intern Med. 2008; 263: 167-8.

37. Terzioglu M, Larsson NG. Mitochondrial dysfunction in mammalian ageing. Novartis Found Symp. 2007; 287: 197-208.

38. Erusalimsky JD. Vascular endothelial senescence: From mechanisms to pathophysiology. J Appl Physiol. 2009; 106: 326-32.

39. Phaneuf S, Leeuwenburgh C. Cytochrome c release from mitochondria in the aging heart: a possible mechanism for apoptosis with age. Am J Physiol Regul Integr Comp Physiol. 2002; 282: 423-30.

40. Csiszar A, Ungvari Z, Koller A, Edwards JG, Kaley G. Proinflammatory phenotype of coronary arteries promotes endothelial apoptosis in aging. Physiol Genomics. 2004; 17: 21-30.

41. Pearson KJ, Baur JA, Lewis KN, Peshkin L, Price NL, Labinskyy $\mathrm{N}$, et al. Resveratrol delays age-related deterioration and mimics transcriptional aspects of dietary restriction without extending life span. Cell Metab. 2008; 8: 157-68.

42. Anversa P, Li P, Sonnenblick EH, Olivetti G. Effects of aging on quantitative structural properties of coronary vasculature and microvasculature in rats. Am J Physiol. 1994; 267: 1062-73.

43. Sonntag WE, Lynch CD, Cooney PT, Hutchins PM. Decreases in cerebral microvasculature with age are associated with the decline in growth hormone and insulin-like growth factor 1. Endocrinology. 1997; 138: 3515-20.

44. Csiszar A, Labinskyy N, Jimenez R, Pinto JT, Ballabh P, Losonczy G, et al. Anti-oxidative and anti-inflammatory vasoprotective effects of caloric restriction in aging: role of circulating factors and SIRT1. Mech Ageing Dev. 2009; 130: 518-27.

45. van der Loo B, Labugger R, Skepper JN, Bachschmid M, Kilo J, Powell JM, et al. Enhanced peroxynitrite formation is associated with vascular aging. J Exp Med. 2000; 192: 1731-44.

46. Ungvari ZI, Labinskyy N, Gupte S, Chander PN, Edwards JG, Csiszar A. Dysregulation of mitochondrial biogenesis in vascular endothelial and smooth muscle cells of aged rats. Am J Physiol Heart Circ Physiol. 2008; 294: 2121-8.

47. Ungvari Z, Bailey-Downs L, Gautam T, Sosnowska D, Wang M, Monticone RE, et al. Age-associated vascular oxidative stress, nrf2 dysfunction and NF- $\{$ kappa $\}$ B activation in the non-human primate macaca mulatta. J Gerontol A Biol Sci Med Sci. 2011; 66: 866-75.

48. Ungvari Z, Bailey-Downs L, Sosnowska D, Gautam T, Koncz P, Losonczy G, et al. Vascular oxidative stress in aging: a homeostatic failure due to dysregulation of NRF2-mediated antioxidant response. Am J Physiol Heart Circ Physiol. 2011; 301: 363-72.

49. Ungvari Z, Parrado-Fernandez C, Csiszar A, de Cabo R. Mechanisms underlying caloric restriction and lifespan regulation: implications for vascular aging. Circ Res. 2008; 102: 519-28.

50. López-Lluch G, Irusta PM, Navas P, de Cabo R. Mitochondrial biogenesis and healthy aging. Exp Gerontol. 2008; 43: 813-9.
51. Levine B, Klionsky DJ. Development by self-digestion: molecular mechanisms and biological functions of autophagy. Dev Cell. 2004; 6: 463-77.

52. Inuzuka Y, Okuda J, Kawashima T, Kato T, Niizuma S, Tamaki Y, et al. Suppression of phosphoinositide 3-kinase prevents cardiac aging in mice. Circulation. 2009; 120: 1695-703.

53. Taneike M, Yamaguchi O, Nakai A, Hikoso S, Takeda T, Mizote I, et al. Inhibition of autophagy in the heart induces age-related cardiomyopathy. Autophagy. 2010; 6: 600-6.

54. Tatsuta T, Langer T. Quality control of mitochondria: protection against neurodegeneration and aging. EMBO J. 2008; 27: 306-14.

55. Wang K, Klionsky DJ. Mitochondria removal by autophagy. Autophagy. 2011; 7: 297-300.

56. Gottlieb RA, Carreira RS. Autophagy in health and disease. 5. Mitophagy as a way of life. Am J Physiol Cell Physiol. 2010; 299: 203-10.

57. Cantó C, Gerhart-Hines Z, Feige JN, Lagouge M, Noriega L, Milne JC, et al. AMPK regulates energy expenditure by modulating NAD+ metabolism and SIRT1 activity. Nature. 2009; 458: 1056-60.

58. Dutta D, Calvani R, Bernabei R, Leeuwenburgh C, Marzetti E. Contribution of impaired mitochondrial autophagy to cardiac aging. Mechanisms and therapeutic opportunities. Circ Res. 2012; 110: 1125-38.

59. Burns EM, Kruckeberg TW, Comerford LE, Buschmann MT. Thinning of capillary walls and declining numbers of endothelial mitochondria in the cerebral cortex of the aging primate, macaca nemestrina. J Gerontol. 1979; 34: 642-50.

60. Burns EM, Kruckeberg TW, Gaetano PK. Changes with age in cerebral capillary morphology. Neurobiol Aging. 1981; 2: 283-91.

61. Ungvari Z, Kaley G, de Cabo R, Sonntag WE, Csiszar A. Mechanisms of vascular aging: new perspectives. J Gerontol A Biol Sci Med Sci. 2010; 65: 1028-41.

62. Nisoli E, Clementi E, Paolucci C, Cozzi V, Tonello C, Sciorati C, et al. Mitochondrial biogenesis in mammals: the role of endogenous nitric oxide. Science. 2003; 299: 896-9.

63. Ryan MT, Hoogenraad NJ. Mitochondrial-nuclear communications. Annu Rev Biochem. 2007; 76: 701-22.

64. Armanios M. Telomeres and age-related disease: how telomere biology informs clinical paradigms. J Clin Invest. 2013; 123: 996-1002.

65. Moyzis RK, Buckingham JM, Cram LS, Dani M, Deaven LL, Jones $\mathrm{MD}$, et al. A highly conserved repetitive DNA sequence, (TTAGGG) $\mathrm{n}$, present at the telomeres of human chromosomes. Proc Natl Acad Sci USA. 1988; 85: 6622-6.

66. Allshire RC, Gosden JR, Cross SH, Cranston G, Rout D, Sugawara N, et al. Telomeric repeat from T. thermophile cross hybridizes with human telomeres. Nature. 1988; 332: 656-9.

67. Vaziri H, Dragowska W, Allsopp RC, Thomas TE, Harley CB, Lansdorp PM. Evidence for a mitotic clock in human hematopoietic stem cells: loss of telomeric DNA with age. Proc Natl Acad Sci USA. 1994; 91: 9857-60.

68. Palm W, de Lange T. How shelterin protects mammalian telomeres. Annu Rev Genet. 2008; 42: 301-34.

69. Greider CW, Blackburn EH. Identification of a specific telomere terminal transferase activity in Tetrahymena extracts. Cell. 1985; 43: 405-13.

70. Greider CW, Blackburn EH. The telomere terminal transferase of Tetrahymena is a ribonucleoprotein enzyme with two kinds of primer specificity. Cell. 1987; 51: 887-98.

71. Greider CW, Blackburn EH. A telomeric sequence in the RNA of Tetrahymena telomerase required for telomere repeat synthesis. Nature. 1989; 337: 331-7.

72. Lingner J, Hughes TR, Shevchenko A, Mann M, Lundblad V, Cech TR. Reverse transcriptase motifs in the catalytic subunit of telomerase. Science. 1997; 276: 561-7. 
73. Feng J, Funk WD, Wang SS, Weinrich SL, Avilion AA, Chiu CP, et al. The RNA component of human telomerase. Science. 1995; 269: 1236-41.

74. d'Adda di Fagagna F, Reaper PM, Clay-Farrace L, Fiegler H, Carr $\mathrm{P}$, Von Zglinicki T, et al. A DNA damage checkpoint response in telomere-initiated senescence. Nature. 2003; 426: 194-8.

75. Sahin E, Depinho RA. Linking functional decline of telomeres, mitochondria and stem cells during ageing. Nature. 2010; 464: 5208.

76. Chin L, Artandi SE, Shen Q, Tam A, Lee SL, Gottlieb GJ, et al. P53 deficiency rescues the adverse effects of telomere loss cooperates with telomere dysfunction to accelerate carcinogenesis. Cell. 1999; 97: $527-38$

77. Moleshi J, DePinho RA, Sahin E. Telomeres and mitochondria in the aging heart. Circ Res. 2012; 110: 1226-37.

78. Sahin E, Colla S, Liesa M, Moslehi J, Müller FL, Guo M, et al. Telomere dysfunction induces metabolic and mitochondrial compromise. Nature. 2011; 470: 359-65.

79. Fuster JJ, Andrés V. Telomere biology and cardiovascular disease. Circ Res. 2006; 99: 1167-80.

80. Gerhard M, Roddy MA, Creager SJ, Creager MA. Aging progressively impairs endothelium-dependent vasodilation in forearm resistance vessels of humans. Hypertension. 1996; 27: 849-53.

81. Avolio AP, Deng FQ, Li WQ, Luo YF, Huang ZD, Xing LF, et al. Effects of aging on arterial distensibility in populations with high and low prevalence of hypertension: Comparison between urban and rural communities in China. Circulation. 1985; 71: 202-10.

82. Lakatta EG. Cardiovascular aging research: the next horizons. J Am Geriatr Soc. 1999; 47: 613-25.

83. McGrath BP, Liang YL, Teede H, Shiel LM, Cameron JD, Dart A. Age-related deterioration in arterial structure and function in postmenopausal women: Impact of hormone replacement therapy. Arterioscler Thromb Vasc Biol. 1998; 18: 1149-56.

84. Tanaka H, Dinenno FA, Monahan KD, Clevenger CM, DeSouza CA, Seals DR. Aging, habitual exercise, and dynamic arterial compliance. Circulation. 2000; 102: 1270-5.

85. Vaitkevicius PV, Fleg JL, Engel JH, O'Connor FC, Wright JG, Lakatta LE, et al. Effects of age and aerobic capacity on arterial stiffness in healthy adults. Circulation. 1993; 88: 1456-62.

86. Kitzman DW, Sheikh KH, Beere PA, Philips JL, Higginbotham MB. Age-related alterations of Doppler left ventricular filling indexes in normal subjects are independent of left ventricular mass, heart rate, contractility and loading conditions. J Am Coll Cardiol. 1991; 18: 1243-50.

87. Port S, Cobb FR, Coleman RE, Jones RH. Effect of age on the response of the left ventricular ejection fraction to exercise. N Engl J Med. 1980; 303: 1133-7.

88. Dai DF, Rabinovitch PS. Cardiac aging in mice and humans: The role of mitochondrial oxidative stress. Trends Cardiovasc Med. 2009; 19: $213-20$

89. Antelmi I, de Paula RS, Shinzato AR, Peres CA, Mansur AJ, Grupi CJ. Influence of age, gender, body mass index, and functional capacity on heart rate variability in a cohort of subjects without heart disease. Am J Cardiol. 2004; 93: 381-5.

90. Fluckiger L, Boivin JM, Quilliot D, Jeandel C, Zannad F. Differential effects of aging on heart rate variability and blood pressure variability. J Gerontol A Biol Sci Med Sci. 1999; 54: 219-24.

91. Schwartz JB, Gibb WJ, Tran T. Aging effects on heart rate variation. J Gerontol. 1991; 46: 99-106.

92. Lakatta EG. Cardiovascular regulatory mechanisms in advanced age Physiol Rev. 1993; 73: 413-67.

93. Lavu S, Boss O, Elliot PJ, Lambert PD. Sirtuins-novel therapeutic targets to treat age-associated diseases. Nat Rev Drug Discov. 2008; 7: 841-53.
94. Hall JA, Dominy JE, Lee Y, Puigserver P. The sirtuin family's role in aging and age-associated pathologies. J Clin Invest. 2013; 123: 973 9.

95. Cohen HY, Miller C, Bitterman KJ, Wall NR, Hekking B, Kessler $\mathrm{B}$, et al. Calorie restriction promotes mammalian cell survival by inducing the SIRT1 deacetylase. Science. 2004; 305: 390-2.

96. Heilbronn LK, Civitarese AE, Bogacka I, Smith SR, Hulver M, Ravussin E. Glucose tolerance and skeletal muscle gene expression in response to alternate day fasting. Obes Res. 2005; 13: 574-81.

97. Nisoli E, Tonello C, Cardile A, Cozzi V, Bracale R, Tedesco L, et al. Calorie restriction promotes mitochondrial biogenesis by inducing the expression of eNOS. Science. 2005; 310: 314-7.

98. Picard F, Kurtev M, Chung N, Topark-Ngarm A, Senawong T, Machado De Oliveira $\mathrm{R}$, et al. Sirt1 promotes fat mobilization in white adipocytes by repressing PPAR-gamma. Nature. 2004; 429: $771-6$

99. Nemoto S, Fergusson MM, Finkel T. SIRT1 functionally interacts with the metabolic regulator and transcriptional coactivator PGC1 alpha\}. J Biol Chem. 2005; 280: 16456-60.

100. Rodgers JT, Lerin C, Haas W, Gygi SP, Spiegelman BM, Puigserver P. Nutrient control of glucose homeostasis through a complex of PGC-1alpha and SIRT1. Nature. 2005; 434: 113-8.

101. Rasbach KA, Schnellmann RG. Isoflavones promote mitochondrial biogenesis. J Pharmacol Exp Ther. 2008; 325: 536-43.

102. Petersen KF, Befroy D, Dufour S, Dziura J, Ariyan C, Rothman $\mathrm{DL}$, et al. Mitochondrial dysfunction in the elderly: possible role in insulin resistance. Science. 2003; 300: 1140-2.

103. Singh KK. Mitochondrial dysfunction is a common phenotype in aging and cancer. Ann NY Acad Sci. 2004; 1019: 260-4.

104. Fontana L, Meyer TE, Klein S, Holloszy JO. Long-term calorie restriction is highly effective in reducing the risk for atherosclerosis in humans. Proc Natl Acad Sci USA. 2004; 101: 6659-63.

105. Hepple RT, Baker DJ, McConkey M, Murynka T, Norris R. Caloric restriction protects mitochondrial function with aging in skeletal and cardiac muscles. Rejuvenation Res. 2006; 9: 219-22.

106. Meyer TE, Kovács SJ, Ehsani AA, Klein S, Holloszy JO, Fontana L. Long-term caloric restriction ameliorates the decline in diastolic function in humans. J Am Coll Cardiol. 2006; 47: 398-402.

107. Minamiyama Y, Bito Y, Takemura S, Takahashi Y, Kodai S, Mizuguchi S, et al. Calorie restriction improves cardiovascular risk factors via reduction of mitochondrial reactive oxygen species in type II diabetic rats. J Pharmacol Exp Ther. 2007; 320: 535-43.

108. Haigis MC, Mostoslavsky R, Haigis KM, Fahie K, Christodoulou DC, Murphy AJ, et al. SIRT4 inhibits glutamate dehydrogenase and opposes the effects of calorie restriction in pancreatic beta cells. Cell 2006; 126: 941-54

109. Liszt G, Ford E, Kurtev M, Guarente L. Mouse Sir2 homolog SIRT6 is a nuclear ADP-ribosyltransferase. J Biol Chem. 2005; 280: 21313-20.

110. Landry J, Sutton A, Tafrov ST, Heller RC, Stebbins J, Pillus L, et al. The silencing protein SIR2 and its homologs are NAD-dependent protein deacetylases. Proc Natl Acad Sci USA. 2000; 97: 5807-11.

111. Imai S, Armstrong CM, Kaeberlein M, Guarente L. Transcriptional silencing and longevity protein Sir2 is an NAD- dependent histone deacetylase. Nature. 2000; 403: 795-800.

112. Smith JS, Brachmann CB, Celic I, Kenna MA, Muhammad S, Starai $\mathrm{VJ}$, et al. A phylogenetically conserved NAD+-dependent protein deacetylase activity in the Sir2 protein family. Proc Natl Acad Sci USA. 2000; 97: 6658-63.

113. Vaziri H, Dessain SK, Ng Eaton E, Imai SI, Frye RA, Pandita TK, et al. hSIR2 (SIRT1) functions as an NAD-dependent p53 deacetylase. Cell. 2001; 107: 149-59.

114. Lagouge M, Argmann C, Gerhart-Hines Z, Meziane H, Lerin C, Daussin F, et al. Resveratrol improves mitochondrial function and 
protects against metabolic disease by activating SIRT1 and PGC1alpha. Cell. 2006; 127: 1109-22.

115. Milne JC, Lambert PD, Schenk S, Carney DP, Smith JJ, Gagne DJ, et al. Small molecule activators of SIRT1 as therapeutics for the treatment of type 2 diabetes. Nature. 2007; 450: 712-6.

116. Yamamoto H, Schoonjans K, Auwerx J. Sirtuin functions in health and disease. Mol Endocrinol. 2007; 21: 1745-55.

117. Yang T, Fu M, Pestell R, Sauve AA. SIRT1 and endocrine signaling. Trends Endocrinol Metab. 2006; 17: 186-91.

118. Li X, Zhang S, Blander G, Tse JG, Krieger M, Guarente L. SIRT1 deacetylates and positively regulates the nuclear receptor LXR. Mol Cell. 2007; 28: 91-106.

119. Freyssenet D. Energy sensing and regulation of gene expression in skeletal muscle. J Appl Physiol. 2007; 102: 529-40.

120. Delmas D, Jannin B, Latruffe N. Resveratrol: preventing properties against vascular alterations and aging. Mol Nutr Food Res. 2005;49: 377-95.

121. Das DK, Maulik N. Resveratrol in cardioprotection: a therapeutic promise of alternative medicine. Mol Interv. 2006; 6: 36-47.

122. Labinskyy N, Csiszar A, Veress G, Stef G, Pacher, Oroszi G, et al. Vascular dysfunction in aging: potential effects of resveratrol, an anti-inflammatory phytoestrogen. Curr Med Chem. 2006; 13: 98996.

123. Mattagajasingh I, Kim CS, Naqvi A, Yamamori T, Hoffman TA, Jung SB, et al. SIRT1 promotes endothelium-dependent vascular relaxation by activating endothelial nitric oxide synthase. Proc Natl Acad Sci USA. 2007; 104: 14855-60.

124. Novakovic A, Bukarica LG, Kanjuh V, Heinle H. Potassium channels-mediated vasorelaxation of rat aorta induced by resveratrol. Basic Clin Pharmacol Toxicol. 2006; 99: 360-4.

125. Stef G, Csiszar A, Lerea K, Ungvari Z, Veress G. Resveratrol inhibits aggregation of platelets from high-risk cardiac patients with aspirin resistance. J Cardiovasc Pharmacol. 2006; 48: 1-5.

126. Zbikowska HM, Olas B, Wachowicz B, Krajewski T. Response of blood platelets to resveratrol. Platelets. 1999; 10: 247-52.

127. Zhang Y, Liu Y, Wang T, Li B, Li H, Wang Z, et al. Resveratrol, a natural ingredient of grape skin: antiarrhythmic efficacy and ionic mechanisms. Biochem Biophys Res Commun. 2006; 340: 1192-9.

128. Zhou B, Wu LJ, Li LH, Tashiro S, Onodera S, Uchiumi F, et al. Silibinin protects against isoproterenol-induced rat cardiac myocyte injury through mitochondrial pathway after up-regulation of SIRT1. J Pharmacol Sci. 2006; 102: 387-95.

129. Teisseyre A, Michalak K. Inhibition of the activity of human lymphocyte Kv1.3 potassium channels by resveratrol. J Membr Biol. 2006; 214: 123-9.

130. Arany Z, He H, Lin J, Hoyer K, Handschin C, Toka O, et al. Transcriptional coactivator PGC-1 alpha controls the energy state and contractile function of cardiac muscle. Cell Metab. 2005; 1 : 259-71.

131. Potente M, Ghaeni L, Baldessari D, Mostoslavsky R, Rossig L, Dequiedt F, et al. SIRT1 controls endothelial angiogenic functions during vascular growth. Genes Dev. 2007; 21: 2644-58.

132. Vahtola E, Louhelainen M, Merasto S, Martonen E, Penttinen S, Aahos I, et al. Forkhead class $\mathrm{O}$ transcription factor 3a activation and Sirtuin1 overexpression in the hypertrophied myocardium of the diabetic Goto-Kakizaki rat. J Hypertens. 2008; 26: 334-44.

133. Alcendor RR, Kirshenbaum LA, Imai S, Vatner SF, Sadoshima J. Silent information regulator 2alpha, a longevity factor and class III histone deacetylase, is an essential endogenous apoptosis inhibitor in cardiac myocytes. Circ Res. 2004; 95: 971-80.

134. Crow MT. Sir-viving cardiac stress: cardioprotection mediated by a longevity gene. Circ Res. 2004; 95: 953-6.

135. Hertweck M, Göbel C, Baumeister R. Elegans SGK-1 is the critical component in the Akt/PKB kinase complex to control stress response and life span. Dev Cell. 2004; 6: 577-88.

136. Ogg S, Paradis S, Gottlieb S, Patterson GI, Lee L, Tissenbaum HA, et al. The fork head transcription factor DAF-16 transduces insulinlike metabolic and longevity signals in C. elegans. Nature. 1997; 389: 994-9.

137. Lin K, Dorman JB, Rodan A, Kenyon C. daf-16: an HNF-3/ forkhead family member that can function to double the life-span of Caenorhabditis elegans. Science. 1997; 278: 1319-22.

138. Henderson ST, Johnson TE. daf-16 integrates developmental and environmental inputs to mediate aging in the nematode Caenorhabditis elegans. Curr Biol. 2001; 11: 1975-80.

139. Lin K, Hsin H, Libina N, Kenyon C. Regulation of the Caenorhabditis elegans longevity protein DAF-16 by insulin/IGF-1 and germline signaling. Nat Genet. 2001; 28: 139-45.

140. Lee SS, Kennedy S, Tolonen AC, Ruvkun G. DAF-16 target genes that control C. elegans life-span and metabolism. Science. 2003; 300: 644-7.

141. Oh SW, Mukhopadhyay A, Dixit BL, Raha T, Green MR, Tissenbaum HA. Identification of direct DAF-16 targets controlling longevity, metabolism and diapause by chromatin immunoprecipitation. Nat Genet. 2006; 38: 251-7.

142. Murphy CT, McCarroll SA, Bargmann CI, Fraser A, Kamath RS, Ahringer J, et al. Genes that act downstream of DAF-16 to influence the lifespan of Caenorhabditis elegans. Nature. 2003; 424: 277-83.

143. Salih DA, Brunet A. FoxO transcription factors in the maintenance of cellular homeostasis during aging. Curr Opin Cell Biol. 2008; 20: 126-36.

144. Nakae J, Kitamura T, Silver DL, Accili D. The forkhead transcription factor Foxo1 (Fkhr) confers insulin sensitivity onto glucose-6phosphatase expression. J Clin Invest. 2001; 108: 1359-67.

145. Puigserver P, Rhee J, Donovan J, Walkey CJ, Yoon JC, Oriente F, et al. Insulin-regulated hepatic gluconeogenesis through FOXO1PGC-1alpha interaction. Nature. 2003; 423: 550-5.

146. Samuel VT, Choi CS, Phillips TG, Romanelli AJ, Geisler JG, Bhanot $\mathrm{S}$, et al. Targeting Foxo1 in mice using antisense oligonucleotide improves hepatic and peripheral insulin action. Diabetes. 2006; 55 : 2042-50

147. Nakae J, Biggs WH 3rd, Kitamura T, Cavenee WK, Wright CV, Arden KC, et al. Regulation of insulin action and pancreatic betacell function by mutated alleles of the gene encoding forkhead transcription factor Foxo1. Nat Genet. 2002; 32: 245-53.

148. Nakae J, Kitamura T, Kitamura Y, Biggs WH 3rd, Arden KC, Accili D. The forkhead transcription factor Foxo1 regulates adipocyte differentiation. Dev Cell. 2003; 4: 119-29.

149. Puig O, Tjian R. Transcriptional feedback control of insulin receptor by dFOXO/FOXO1. Genes Dev. 2005; 19: 2435-46.

150. Russell SJ, Kahn CR. Endocrine regulation of ageing. Nat Rev Mol Cell Biol. 2007; 8: 681-91.

151. Oellerich MF, Potente M. FOXOs and Sirtuins in Vascular Growth, Maintenance, and Aging. Circ Res. 2012; 110: 1238-51.

152. Fontana L, Partridge L, Longo VD. Extending healthy life spanfrom yeast to humans. Science. 2010; 328: 321-6.

153. Castello L, Froio T, Cavallini G, Biasi F, Sapino A, Leonarduzzi $\mathrm{G}$, et al. Calorie restriction protects against age-related rat aorta sclerosis. FASEB J. 2005; 19: 1863-65.

154. Guo Z, Mitchell-Raymundo F, Yang H, Ikeno Y, Nelson J, Diaz V, et al. Dietary restriction reduces atherosclerosis and oxidative stress in the aorta of apolipoprotein E-deficient mice. Mech Aging Dev. 2002; 123: 1121-31.

155. Haddad F, Bodell PW, McCue SA, Herrick RE, Baldwin KM. Food restriction-induced transformations in cardiac functional and biochemical properties in rats. J Appl Physiol. 1993; 74: 606-12.

156. Seymour EM, Parikh RV, Singer AA, Bolling SF. Moderate calorie restriction improves cardiac remodeling and diastolic dysfunction 
in the Dahl-SS rat. J Mol Cell Cardiol. 2006; 41: 661-8.

157. Taffet GE, Pham TT, Hartley CJ. The age-associated alterations in late diastolic function in mice are improved by caloric restriction. J Gerontol A Biol Sci Med Sci. 1997; 52: 285-90.

158. Mager DE, Wan R, Brown M, Cheng A, Wareski P, Abernethy $\mathrm{DR}$, et al. Caloric restriction and intermittent fasting alter spectral measures of heart rate and blood pressure variability in rats. FASEB J. 2006; 20: 631-7.

159. Colman RJ, Anderson RM, Johnson SC, Kastman EK, Kosmatka $\mathrm{KJ}$, Beasley TM, et al. Caloric restriction delays disease onset and mortality in rhesus monkeys. Science. 2009; 325: 201-4.

160. Dolinsky VW, Morton JS, Oka T, Robillard-Frayne I, Bagdan M, Lopaschuk GD, et al. Calorie restriction prevents hypertension and cardiac hypertrophy in the spontaneously hypertensive rat. Hypertension. 2010; 56: 412-21.

161. Rippe C, Lesniewski L, Connell M, LaRocca T, Donato A, Seals D. Short-term calorie restriction reverses vascular endothelial dysfunction in old mice by increasing nitric oxide and reducing oxidative stress. Aging Cell. 2010; 9: 304-12.

162. Maeda H, Gleiser CA, Masoro EJ, Murata I, McMahan CA, Yu BP. Nutritional influences on aging of fischer 344 rats: II. Pathology. J Gerontol. 1985; 40: 671-88.

163. Fontana L, Vinciguerra M, Longo VD. Growth factors, nutrient signaling, and cardiovascular aging. Circ Res. 2012; 110: 1139-50.

164. Speakman JR, Mitchell SE. Caloric restriction. Mol Aspects Med. 2011; 32: 159-221.

165. Hars ES, Qi H, Ryazanov AG, Jin S, Cai L, Hu C, et al. Autophagy regulates aging in C. elegans. Autophagy. 2007; 3: 93-5.

166. Tóth ML, Sigmond T, Borsos E, Barna J, Erdélyi P, Takács-Vellai K, et al. Longevity pathways converge on autophagy genes to regulate life span in Caenorhabditis elegans. Autophagy. 2008; 4: 330-8.

167. Morselli E, Maiuri MC, Markaki M, Megalou E, Pasparaki A, Palikaras $\mathrm{K}$, et al. Caloric restriction and resveratrol promote longevity through the Sirtuin-1-dependent induction of autophagy. Cell Death Dis. 2010; 1: 10.

168. Fontana L, Klein S. Aging, adiposity, and calorie restriction. JAMA. 2007; 297: 986-94.

169. Nguyen T, Nioi P, Pickett CB. The nrf2-antioxidant response element signaling pathway and its activation by oxidative stress. $\mathrm{J}$ Biol Chem. 2009; 284: 13291-5.

170. Kobayashi M, Yamamoto M. Nrf2-keap1 regulation of cellular defense mechanisms against electrophiles and reactive oxygen species. Adv Enzyme Regul. 2006; 46: 113-40.

171. Ishii T, Itoh K, Yamamoto M. Roles of nrf2 in activation of antioxidant enzyme genes via antioxidant responsive elements. Methods Enzymol. 2002; 348: 182-90.

172. Zou Y, Jung KJ, Kim JW, Yu BP, Chung HY. Alteration of soluble adhesion molecules during aging and their modulation by calorie restriction. FASEB J. 2004; 18: 320-2.

173. Weiss EP, Racette SB, Villareal DT, Fontana L, Steger-May $\mathrm{K}$, Schechtman $\mathrm{KB}$, et al. Improvements in glucose tolerance and insulin action induced by increasing energy expenditure or decreasing energy intake: a randomized controlled trial. Am J Clin Nutr. 2006; 84: 1033-42.

174. Guo Z, Mitchell-Raymundo F, Yang H, Ikeno Y, Nelson J, Diaz V, et al. Dietary restriction reduces atherosclerosis and oxidative stress in the aorta of apolipoprotein e-deficient mice. Mech Aging Dev. 2002; 123:1121-31.

175. Ahmet I, Tae HJ, de Cabo R, Lakatta EG, Talan MI. Effects of calorie restriction on cardioprotection and cardiovascular health. $\mathrm{J}$ Mol Cell Cardiol. 2011; 51: 263-71.

176. Kemi M, Keenan KP, McCoy C, Hoe CM, Soper KA, Ballam GC, et al. The relative protective effects of moderate dietary restriction versus dietary modification on spontaneous cardiomyopathy in male Sprague-Dawley rats. Toxicol Pathol. 2000; 28: 85-96.
177. Navarro F, Navas P, Burgess JR, Bello RI, De Cabo R, Arroyo A, et al. Vitamin $\mathrm{E}$ and selenium deficiency induces expression of the ubiquinone-dependent antioxidant system at the plasma membrane. FASEB J. 1998; 12: 1665-73.

178. Navas P, Fernandez-Ayala DM, Martin SF, Lopez-Lluch G, De Caboa R, Rodriguez-Aguilera JC, et al. Ceramide-dependent caspase 3 activation is prevented by coenzyme Q from plasma membrane in serum-deprived cells. Free Radic Res. 2002; 36: 36974.

179. Navas P, Villalba JM, de Cabo R. The importance of plasma membrane coenzyme $Q$ in aging and stress responses. Mitochondrion. 2007; 7: 34-40.

180. Villalba JM, Crane FL, Navas P. Plasma Membrane Redox System and their role in Biological Stress and Disease. In: Asard H, Berczi A, Caubergs RJ, eds. Plasma Membrane Redox Systems and Their Role in Biological Stress and Disease. Vol 1. Dordrecht, The Netherlands: Kluwer; 1998.

181. Villalba JM, Navarro F, Córdoba F, Serrano A, Arroyo A, Crane $\mathrm{FL}$, et al. Coenzyme Q reductase from liver plasma membrane: purification and role in trans-plasma-membrane electron transport. Proc Natl Acad Sci USA. 1995; 92: 4887-91.

182. Hyun DH, Emerson SS, Jo DG, Mattson MP, de Cabo R. Calorie restriction up-regulates the plasma membrane redox system in brain cells and suppresses oxidative stress during aging. Proc Natl Acad Sci USA. 2006; 103: 19908-12.

183. De Cabo R, Cabello R, Rios M, López-Lluch G, Ingram DK, Lane $\mathrm{MA}$, et al. Calorie restriction attenuates age-related alterations in the plasma membrane antioxidant system in rat liver. Exp Gerontol. 2004; 39: 297-304.

184. Hyun DH, Hunt ND, Emerson SS, Hernandez JO, Mattson MP, de Cabo R. Up-regulation of plasma membrane-associated redox activities in neuronal cells lacking functional mitochondria. $\mathrm{J}$ Neurochem. 2007; 100: 1364-74.

185. López-Lluch G, Rios G, Lane MA, Navas P, de Cabo R. Mouse liver plasma membrane redox system activity is altered by aging and modulated by calorie restriction. Age. 2005; 27: 153-60.

186. Lim GP, Calon F, Morihara T, Yang F, Teter B, Ubeda O, et al. A diet enriched with the omega- 3 fatty acid docosahexaenoic acid reduces amyloid burden in an aged Alzheimer mouse model. J Neurosci. 2005; 25: 3032-40.

187. Zheng J, Mutcherson R 2nd, Helfand SL. Calorie restriction delays lipid oxidative damage in Drosophila melanogaster. Aging Cell. 2005; 4: 209-16.

188. Baur JA, Pearson KJ, Price NL, Jamieson HA, Lerin C, Kalra A, et al. Resveratrol improves health and survival of mice on a highcalorie diet. Nature. 2006; 444: 337-42.

189. Pearson KJ, Baur JA, Lewis KN, Peshkin L, Price NL, Labinskyy $\mathrm{N}$, et al. Resveratrol delays age-related deterioration and mimics transcriptional aspects of dietary restriction without extending life span. Cell Metab. 2008; 8: 157-68.

190. Harrison DE, Strong R, Sharp ZD, Nelson JF, Astle CM, Flurkey $\mathrm{K}$, et al. Rapamycin fed late in life extends lifespan in genetically heterogeneous mice. Nature. 2009; 460: 392-5.

191. Dhahbi JM, Mote PL, Fahy GM, Spindler SR. Identification of potential caloric restriction mimetics by microarray profiling. Physiol Genom. 2005; 23: 343-50.

192. Boström P, Wu J, Jedrychowski MP, Korde A, Ye L, Lo JC, et al. A pgc1-alpha-dependent myokine that drives brown-fat-like development of white fat and thermogenesis. Nature. 2012; 481: 463-8.

193. Barger JL, Kayo T, Pugh TD, Prolla TA, Weindruch R. Short-term consumption of a resveratrol-containing nutraceutical mixture mimics gene expression of long-term caloric restriction in mouse heart. Exp Gerontol. 2008; 43: 859-66. 